Middle East Journal of Science

Research Article

\title{
EXAMINATION OF APOPTOTIC CHANGES IN AROMATIC HYDROCARBON BENZENE ADMINISTERED RAT TESTICULAR TISSUE WITH HISTOPATHOLOGICAL METHODS
}

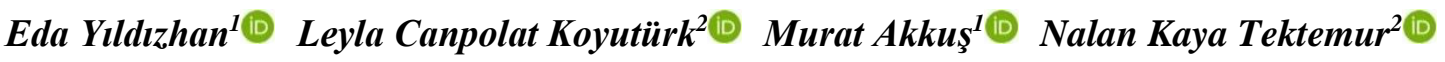 \\ Ebru Gökalp Özkorkmaz ${ }^{1 \mathbb{1} *} \quad$ Furat Aşır ${ }^{1 \mathbb{C}}$ \\ ${ }^{1}$ Dicle University Faculty of Medicine Department of Histology and Embryology, Diyarbakır, Turkey \\ ${ }^{2}$ Firat University Faculty of Medicine Department of Histology and Embryology, Elazı $\breve{g}$, Turkey \\ Corresponding author:ebrug76@gmail.com
}

\begin{abstract}
Benzene is an aromatic hydrocarbon and a colorless and odorous liquid. It is used in the production of plastics, detergents, pesticides, and other chemicals. Serious deterioration is seen in sperm production of men who are exposed to hydrocarbons such as ethylbenzene, toluene, xylene, and aromatic solvents found in paints, lacquers, adhesive-like substances in their professions. The purpose of this study was to examine the possible effects of benzene on testicular tissues via histopathological and TUNEL staining methods. In this study, healthy 18 Wistar albino male rats, with a mean age of 810 weeks weighing 250-300 g were used. Rats were divided into 3 groups; Group I was the control group. Group II was administered $1 \mathrm{ml} / \mathrm{kg}$ benzene for 9 days and Group III $1.5 \mathrm{ml} / \mathrm{kg}$ benzene for 5 days via orogastric tube. At the end of the experiment, all rats were decapitated, and their testicular tissues were excised. Stained with Haematoxylin and Eosin, Johnsen scoring was performed for each group. Apoptosis was demonstrated with TUNEL method, marked with the Image J program and statistical analysis was performed. Benzene exposed rat testicular tissues depicted thinning of seminiferous tubule epithelium cytoplasmic vacuoles, affusion of seminiferous tubule epithelium to the lumen, and affusion in spermatogenic cells (desquamation), degenerative changes in germ cells (spermatogonia), degenerative tubule structures, disorganized interstitial tissues, and absence of epithelial integrity were observed. Compared with the control group, the rats exposed to benzene revealed a significant increase in apoptotic cells in the seminiferous tubules via TUNEL staining. It was thought that exposure to benzene resulted in degeneration and increased apoptotic cells in the testicular tissues.
\end{abstract}

Keywords: Benzene, Testis, Histopathology, TUNEL staining, Apoptosis

Received: May 19, $2021 \quad$ Accepted: June 21, 2021

\section{Introduction}

Benzene, an aromatic hydrocarbon, causes significant damage when taken into the body $[1,2]$. According to EU classification of CMR (Carcinogenic, Mutagenic, Reprotoxic) substances (EU legislation- CLP 1272/2008) and the International Agency for Research on Cancer (IARC), benzene is classified as carcinogenic (1A), mutagenic (1B), and reprotoxic (Reproductive Toxic Substance). The way CMRs enter the organisms can be through inhalation (dust, smoke, gas, vapor), ingestion (by eating or drinking with dirty hands, smoking or accidentally swallowing), and through (intact or damaged) skin and mucous membranes. From the perspective of occupational health and safety, examples of exposure 
to carcinogens such as benzene can be given from different activity sectors. Workplace employees are exposed to benzene in pure or hydrocarbon mixtures in the refinery, through steam and skin contact in mechanical works, during transfer in the fuel transport area [3-5]. Benzene causes leukemia and aplastic anemia in exposed workers and has been associated with immune system abnormalities [6]. Prolonged inhalation of benzene vapor causes reduction of red and white blood cells in the blood [7]. Benzene shows its reprotoxic effect on the male reproductive system by affecting steroid hormones, sperm quality, and concentration [8,9]. Benzene has been found to cause a decrease in spermatogenesis by affecting androgens [10] however, an improvement in spermatogenesis occurs when androgen therapy is applied [11]. Effects of benzene on the female reproductive system have been also proven. It causes an increased frequency of oligomenorrhea in women exposed to high doses of organic solvents (benzene, xylene, or toluene) [12]. After benzene enters the organism, it is metabolized in the liver via the Cytochrome P450 2E1 enzyme system. The resulting intermediates (hydroquinone, phenol, catechol, benzoquinone, muconaldehyde) have been reported to cause toxicity [13]. These metabolites are responsible for genotoxicity and hematotoxicity [14].

Apoptosis is a programmed, energy-requiring active cell death $[15,16]$. The structural features of apoptosis are the shrinkage of the cell, the condensation of chromatin in the nucleus and its localization on the nucleus membrane, DNA fragmentation, karyorrhexis, condensation of cytoplasm, compact organelles, blebbing of the cell membrane, and the formation of apoptotic bodies [17]. Cellular apoptosis is one of the important processes observed in testicular development and normal spermatogenesis. Spermatogenesis is a complex process that requires homeostasis of different cell types. Sertoli cells, regulating germ cell proliferation and differentiation, play a role in the control of germ cell apoptosis [18]. Apoptotic events seen in ejaculated human spermatozoa are caspase activation, phosphatidylserine externalization, and alteration of mitochondrial membrane potential, and DNA fragmentation. These processes are frequent in non-fertile men and functionally insufficient sperm. The importance of the apoptotic pathway in spermatogenesis and sperm maturation can be expressed by eliminating defective germ cells in the testis and epididymis and ensuring quality control in sperm production [19].

This study aimed to examine the apoptotic effects of benzene toxicity on rat testicular tissue via histopathological methods.

\section{Material and Method}

\subsection{Ethical approval and experimental model}

Firat University Local Ethics Committee approved all experimental procedures. (Decision Date: 04.04.2013; Decision number: 2013/14). The study was completed in accordance with the ethical procedures in the 'Guide for the Care and Use of Laboratory Animals' published by the National Research Council [20]. Male Wistar Albino rats (n: 18) weighing 250-300 grams, 8-10 weeks of age, were obtained from Firat University Experimental Research Center (FÜDAM). During the study, rats were allowed to access water and fed ad libitum at room temperature of $25 \mathrm{C}^{\circ}, 12 / 12 \mathrm{~h} \mathrm{light/} \mathrm{dark} \mathrm{period}$. Rats were assigned to three groups (6 rats per group). Group I control; only saline ( $1 \mathrm{ml} / \mathrm{kg}$ ) was administered orogastric during the experiment. Group II, $1 \mathrm{ml} / \mathrm{kg}$ benzene (Benzene anhydrous, 99.8\%, Cas no: 71-43-2, Sigma-Aldrich, Germany) was administered at the same time interval every day for 9 days with an orogastric catheter. Group III, $1.5 \mathrm{ml} / \mathrm{kg}$ benzene was administered at the same time interval every day for 5 days with an orogastric catheter. 


\subsection{Histological tissue processing protocol}

All rats were sacrificed under anesthesia $(90 \mathrm{mg} / \mathrm{kg}$ intramuscular ketamine hydrochloride, (Ketalar, Pfizer, Turkey) and $10 \mathrm{mg} / \mathrm{kg}$ xylazine (Rompun, Bayer, Turkey) at the end of the $5^{\text {th }}$ and $9^{\text {th }}$ days. Testicles were removed quickly. Testicular tissues were processed for routine paraffin wax tissue protocol as follows; excised tissues were fixed in Bouin solution. After fixation, they were dehydrated in ascending alcohol series (70\%-80\%-96\%-100\%) and cleared in xylene for 25 min two times, and embedded in paraffin blocks (Sigma, Germany). 5- $\mu \mathrm{m}$ sections from paraffin blocks were cut with a microtome (Leica, Germany), stained with Hematoxylin-Eosin (H\&E), examined by light microscopy (Zeiss, Imager A2, Germany).

\subsection{TUNEL method}

Apoptosis in testicular tissue sections was evaluated by TUNEL method for each group. Apoptotic cells were stained with ApopTag plus Peroxidase in Situ Apoptosis Detection Kit (Chemicon, cat no: S7101, US) on the sections. Endogenous peroxidase activity was blocked by $3 \%$ hydrogen peroxide $(5 \mathrm{~min}$ ) and then tissues were treated with $0.05 \%$ proteinase $\mathrm{K}$ for $10 \mathrm{~min}$. Tissues were washed in PBS and incubated with equilibration buffer $(6 \mathrm{~min})$, then incubated with the working solution (60 $\min , 70 \mu 1$ reaction buffer $+30 \%$ TdT Enzyme) at $37^{\circ} \mathrm{C}$ in a humid environment. After the application of stop /wash buffer (10 min), sections were incubated with anti-digoxigenin-peroxidase for 30 minutes. Diaminobenzidine (DAB) substrate was used as a chromogen to show apoptotic cells. Harris hematoxylin was used as a contrast staining. TUNEL staining evaluation was performed with a semiquantitative scoring using a number from 0 (no expression) to +3 (strong) based on the prevalence of the staining.

\subsection{Johnsen testicular biopsy scoring}

Testicular biopsy scoring criteria of Johnsen et al. [21] were used in the biostatistical evaluation of spermatogenesis (Table 1). A number of 90 seminiferous tubules were subjected to testicular biopsy scoring. Scoring of the data was performed in a blind manner by the histopathologists for each group under the light microscope.

Table 1. Johnsen testicular biopsy scoring criteria

\begin{tabular}{lc}
\hline Johnsen Biopsy Scoring Table & Score \\
\hline Regular, dense spermatogenesis and tubule structure & 10 \\
Dense spermatozoa in the lumen but irregularity in the spermatogenic line & 9 \\
The small amount of spermatozoa present in the lumen & 8 \\
No spermatozoa in the lumen but spermatids are present & 7 \\
The low number of spermatids & 6 \\
No spermatozoa and spermatids but dense spermatocytes & 5 \\
Low amount of spermatocytes & 4 \\
Only Spermatogonia available & 3 \\
There are no germ cells & 2 \\
No germ cells or Sertoli cells & 1 \\
\hline
\end{tabular}




\subsection{Image $J$ analysis}

Image $\mathrm{J}$ version $1.35 \mathrm{f}$ was also used for apoptotic cell examination using the TUNEL technique. 10 seminiferous tubules were selected in the cross-sectional area and the chromogen reaction (brownish stained cells) was counted. The percentage result was obtained by proportioning the total number of cells in the seminiferous tubule to the total number. Cells that react to chromogen and cells that do not (cells stained in the bluish pattern) were marked with two different markers in the Image J program and then counted. Percentage calculations of all groups were obtained.

\subsection{Statistical analysis}

All statistical analyses were made with IBM SPSS 25 software (SPSS Inc. Chicago, IL) application. Shapiro-Wilk tests were used for normality tests and normality of distributions. Normal distributed measurements were analyzed with the One Way Anova test. The comparison between the groups was evaluated with the Post-Hoc Turkey test. Any p-value lower than 0.05 was accepted statistically significant.

\section{Results}

\subsection{Hematoxylin-Eosin findings}

In the control group, seminiferous tubules, basal lamina of seminiferous tubules, cells belonging to the spermatogenic series, Sertoli cells, and Leydig cells were observed in normal structure (Figure 1a). In Group II, tubule structures seemed to be preserved, and degeneration and pyknosis in the spermatogenic line, fibrosis in the interstitium, and cytoplasmic vacuoles were observed (Figure 1b). In group III, it was observed that there were more degenerative changes in the rat testes compared to Group II; desquamation due to degeneration in spermatogenic cells, pyknosis, cytoplasmic vacuoles in the interstitial area, pyknosis in the Leydig cells, and the tubule structure was disrupted (Figure 1c).

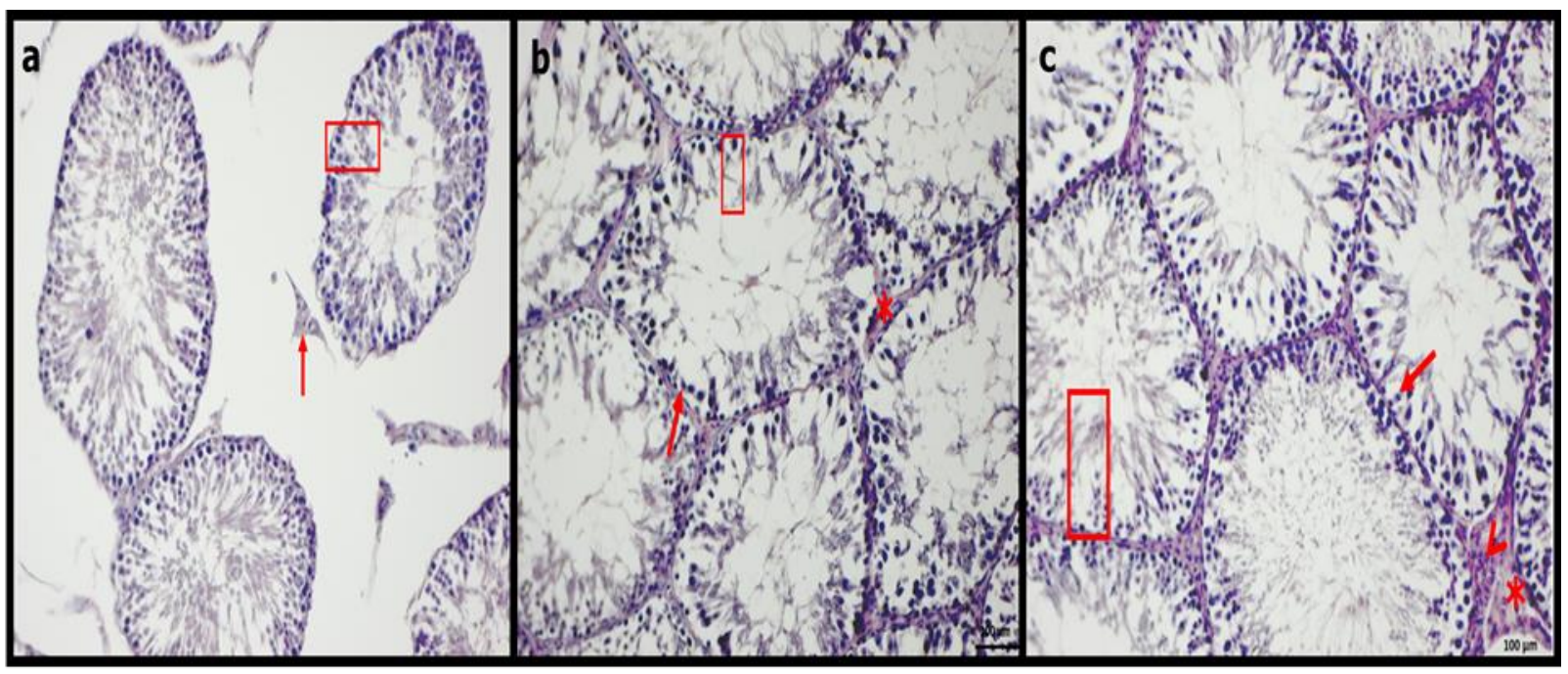

Figure 1a. Control group rat testis tissue. Normal histological appearance. Leydig cells (red arrow) and germinal epithelium (red rectangle). H\&E staining, Bar: $100 \mu \mathrm{m}$. 1b. Group II rat testis cross section. Degeneration (rectangle) and pyknosis arrow) in the spermatogenic line, fibrosis in the interstitium (asteriks), H\&E staining, Bar: $100 \mu \mathrm{m}$ 1c. Group III rat testis section. Degeneration in spermatogenic cells (desquamation) (rectangle) and pyknosis (red arrow), cytoplasmic vacuoles in the interstitial area (asteriks), pyknosis (red arrowhead) in Leydig cells, deterioration in tubule structure. H\&E staining, Bar: $100 \mu \mathrm{m}$ 


\subsection{TUNEL results}

In TUNEL staining for apoptotic examinations, TUNEL positivity was observed with a prevalence of +1 in the control group (Figure 2a). Compared to the control group, it was observed to have a spread of +3 in Group II and Group III groups (Figures $2 b$ and $2 c$, respectively). There was no difference in TUNEL positivity between Group II and Group III groups.

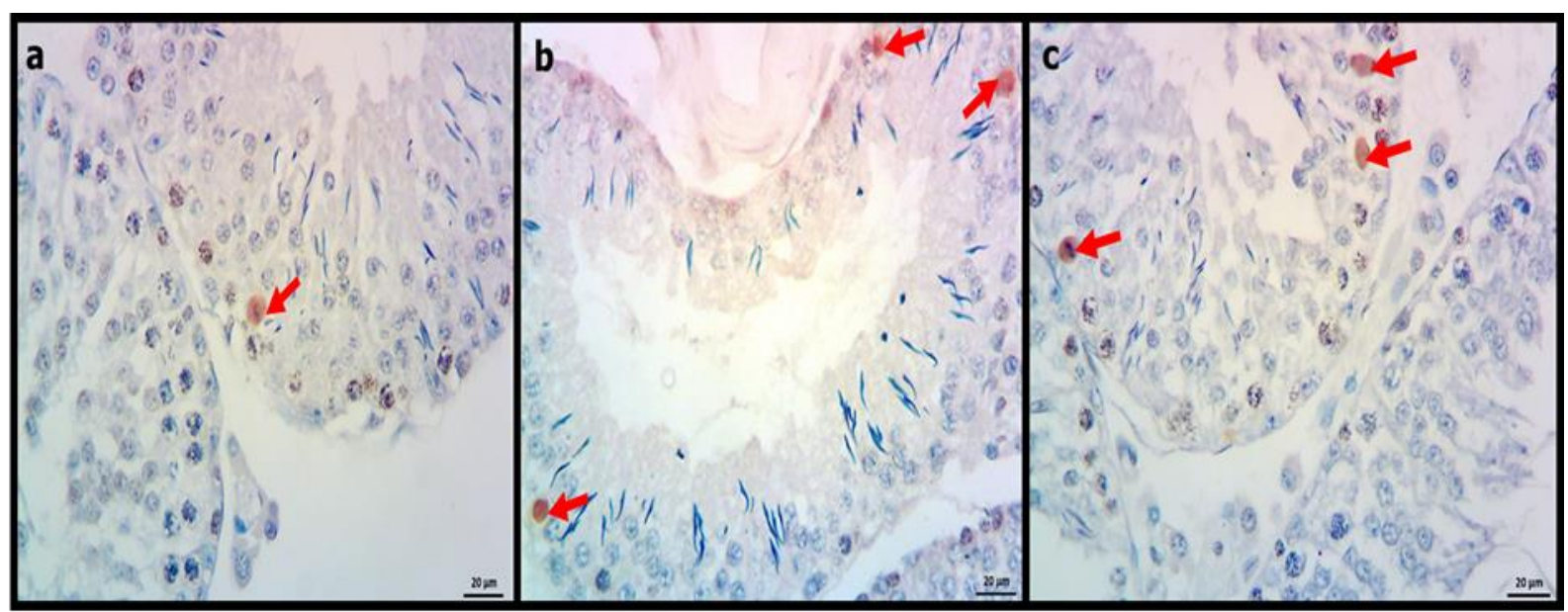

Figure 2a. TUNEL positive cell in the control group (red arrow). TUNEL staining, Bar: $20 \mu \mathrm{m}$. $2 \mathbf{b}$. Group II TUNEL positive apoptotic cell (red arrows). TUNEL staining, Bar: $20 \mu \mathrm{m}$. 2c. Group III TUNEL positive apoptotic cell (red arrows). TUNEL staining, Bar: $20 \mu \mathrm{m}$

Marking of apoptotic cells determined by TUNEL technique with Image J program for statistical analysis is as in Figure 3a-c. The statistical analysis of Johnsen scoring revealed a significant difference when the control group was compared with Group II and Group III $(p=0.01)$ (Table 2). There was no statistical difference between Group II and Group III ( $p=0.315$ ) (Figure 4). The average percentage distribution of the groups according to Image $\mathbf{J}$ analysis results was given in Table 3 . The highest percentage was in Group III $(0.19 \%)$ whereas the lowest one was in Group I $(0.09 \%)$.

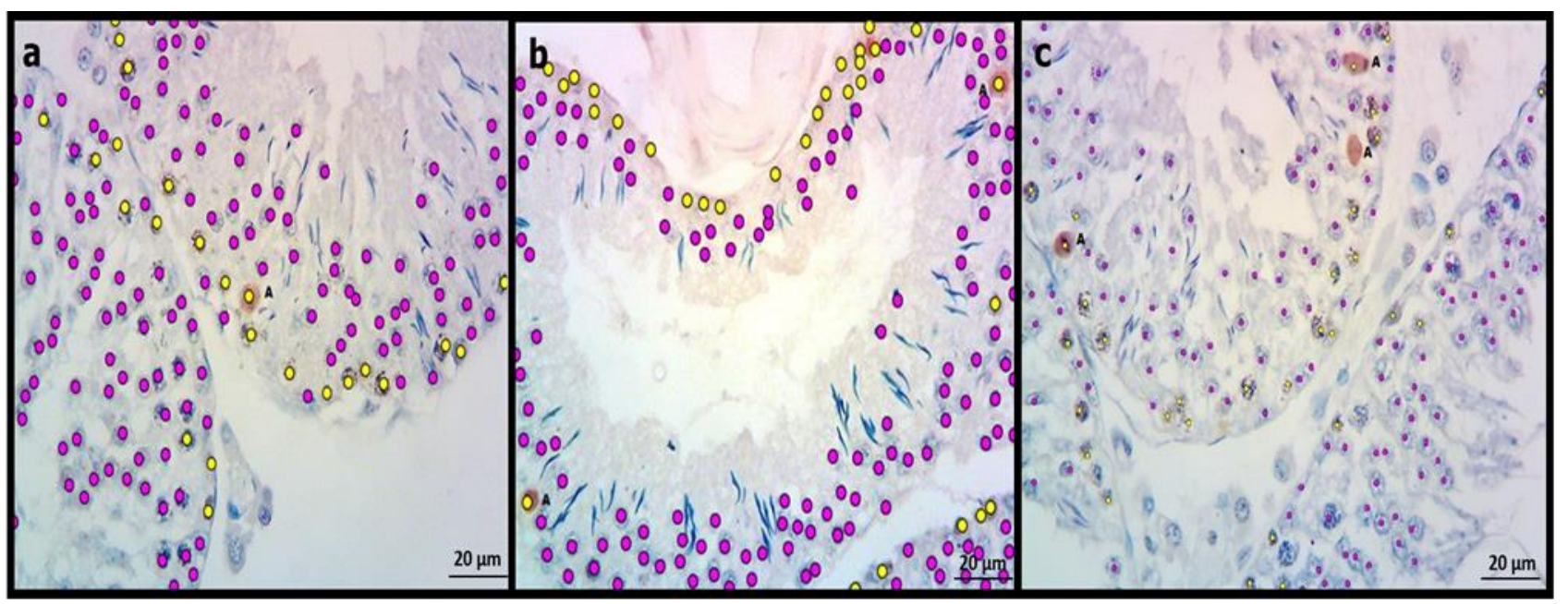

Figure 3 a,b,c. Image $\mathbf{J}$ analysis of TUNEL staining in all groups. TUNEL positive (yellow) and negative (pink) marked cell nuclei in Group I(control), Group II, Group III respectively. 
Table 2. Johnsen scoring of groups

\begin{tabular}{lll}
\hline Groups & Median (min-max) & Statistical significance \\
\hline Group I (Control) & $9.50(8.00-10.00)$ & $\mathrm{p}=0.001$ (compared with group II and III) \\
Group II (1 ml Benzene) & $3.00(1.00-6.00)$ & $\mathrm{p}=0.315$ (compared to group I) \\
Group III (1.5 ml Benzene) & $2.00(0.00-5.00)$ & $\mathrm{p}=0.315$ (compared to group I) \\
\hline
\end{tabular}

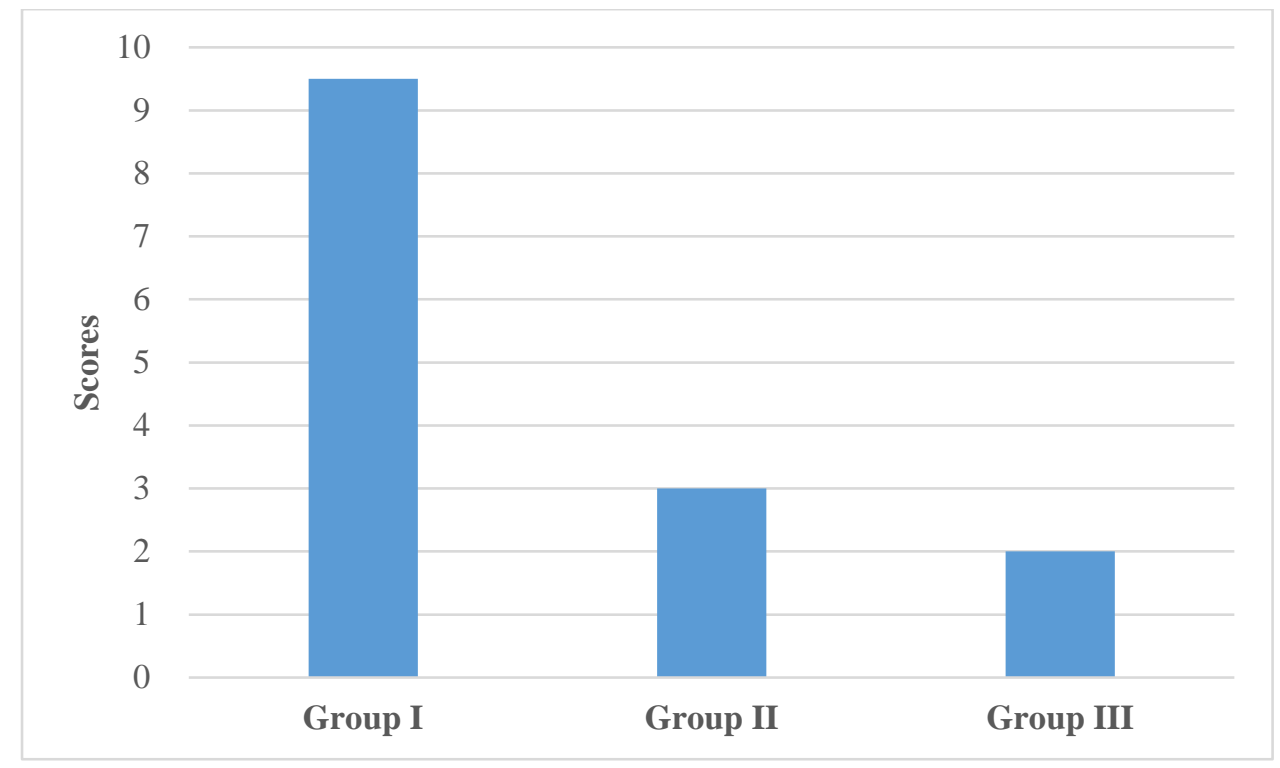

Figure 4. Chart showing Johnsen scoring for quantifying spermatogenesis. Spermatic cells were significantly lower in Group II and Group III than that of control I $(p=0.01)$. Scores of Group II and Group III were significantly close to each other $(p=0.315)$.

Table 3. Average percentage distribution of the groups according to Image $\mathrm{J}$ analysis results.

\begin{tabular}{lccc}
\hline Groups & $\begin{array}{c}\text { Negative reaction } \\
\text { (cell) }\end{array}$ & $\begin{array}{c}\text { Positive reaction } \\
\text { (cell) }\end{array}$ & Percentages \\
\hline $\begin{array}{l}\text { Group I } \\
\text { (Control) }\end{array}$ & 156 & 17 & $0.09 \%$ \\
$\begin{array}{l}\text { Group II } \\
(\mathbf{1} \text { ml Benzene) }\end{array}$ & 135 & 30 & $0.18 \%$ \\
$\begin{array}{l}\text { Group III } \\
(\mathbf{1 . 5} \text { ml Benzene) }\end{array}$ & 128 & 31 & $0.19 \%$ \\
\hline
\end{tabular}

\section{Discussion}

Since most of the organic solvents commonly used in the industry are volatile compounds, they show their effects on living things through respiration. These compounds enter the organism through inhalation as well as orally and through the skin, causing significant damage [22]. Skin contact of organic solvents is known to cause eczema on the skin, prolonged inhalation of its vapor to the reduction of red and white blood cells, genotoxicity, hematoxicity and leukemia, liver damage, and chromosome aberration [6,7,22]. The median lethal dose (LD50) for benzene changes from 0.93 to $5.96 \mathrm{~g} / \mathrm{kg}$ [23, 24]. A 4 -week exposure of mice to $>=8 \mathrm{mg}$ of benzene $/ \mathrm{kg} / \mathrm{day}$ in the drinking water induced the synthesis 
and catabolism of monoamine neurotransmitters and produced dose-related decreases in red-blood-cell parameters and lymphocyte numbers [25]. Previous literature revealed that the main toxic effect of benzene is related to the hematopoietic system and is of great importance in terms of reproductive health. The rate of infertility is increasing day by day in the community. Exposure to chemicals that affect reproductive health such as benzene for various reasons is a cause of both male and female infertility. Singh R. et al. administered benzene orally with 0.5 and $1 \mathrm{ml} / \mathrm{kg}(-1)$ doses of benzene for 14 and 9 days, respectively. They have observed all germ cell types (spermatogenesis, primary spermatocyte, spermatid in seminiferous tubules), Sertoli cells and interstitial Leydig cells in healthy testicular tissue have normal morphological appearance however, in the benzene group, they have found giant cell formation in the seminiferous tubule epithelium, cytoplasmic vacuoles, chromatolysis, shedding of germ cells into the tubular lumen, and elongated appearance in Leydig cells. They also observed that the degeneration in the seminiferous tubule was more evident in the high-dose benzene group, as well [26]. In our study, we preferred to give at the dosages of $1 \mathrm{ml} / \mathrm{kg}$ and $1.5 \mathrm{ml} / \mathrm{kg}$. We observed irregularity due to degeneration in the seminiferous tubule epithelium, cytoplasmic vacuoles in the seminiferous tubule, shedding in the seminiferous tubule epithelium and spermatogenic cells, pyknosis in Leydig cells were observed (Figure 1b, c). Although the findings were consistent with the previous studies, no evaluation could be made in terms of chromatolysis. More degenerative changes were observed in the testicles of rats exposed to benzene at higher doses (Group III). Ravindranath et al. observed inhibition of spermatogenesis, damage to seminiferous tubules, reduction in the number and size of interstitial Leydig cells, degenerative changes in the cytoplasm of Sertoli cells and nuclei of spermatocytes [27]. Ralph et al. reported that benzene has a negative effect on sperm production, and disrupts the structure of spermatogonias during developmental stages [28]. The effect of benzene on spermatogenic cells may result in infertility was indicated by Cardenas-Valencia et al. [29].

In our study, as a result of the benzene effect on spermatogenic cells, the structure of the seminiferous tubule degenerated therewithal, the structures of some tubules were completely disrupted and this may result in infertility. In another study conducted on mouse testicular tissue, it was reported that benzene caused degenerative changes in spermatogenic cells, Sertoli cells, and seminiferous tubule epithelium due to the increase in the dose amount, which may lead to testicular cancer [30]. A study by Shi et al. revealed that above $30 \mu \mathrm{M}$ benzene exposure causes an increase in apoptosis in testicular germ cells [31]. These findings are in harmony with our study. According to the results of TUNEL staining applied to determine apoptosis, we observed that there was an increase in apoptosis in the benzene administered groups compared to the control group, but there was no significant difference between the benzene administered groups (Figure $2 \mathrm{a}, \mathrm{b}$ ).

By virtue of the difference between Group II and Group III was not statistically significant when compared to each other (Figure 4), we thought that increasing the dose and shortening the duration and decreasing the dose, and increasing the duration have the same effect. Additionally, the fact that cellular apoptosis was higher in Group II and Group III compared to the control group means that benzene may have induced apoptosis and caused an excessive increase in cell death rate thus infertility in testicular tissue.

In conclusion, it was observed that benzene exposure caused toxicity in testicular tissue resulting in degeneration in tissue structure, and apoptotic cell increment in spermatogenic cells that may lead to infertility. Following safe working procedures and staying as far as possible from benzene are important to prevent male infertility due to benzene exposure. 


\section{Ethical statement:}

This study was approved by Frrat University Local Ethics Committee. (Decision Date: 04.04.2013; Decision number: 2013/14).

\section{Acknowledgment}

This study was supported by Frrat University Scientific Research Projects Coordination Unit (FUBAP) with the T. F. 13. 26 project number. The study was presented orally at the 24th National Electron Microscopy Congress (April 2019, Edirne, Turkey) (SB-06).

\section{Conflict of interest:}

The authors declare that there are no conflicts of interest.

\section{Authors' Contributions:}

E.Y. performed histopathological experiments, obtained the data, wrote the first draft. L.C.K. and M. A. designed and directed the project, discussed the results. N.K.T. performed animal experiments and ethical procedures. E.G.Ö. and F.A. analysed the data, wrote the final draft.

All authors read and approved the final manuscript.

\section{References}

[1] Adel-Shafy, H.I., Mansour, M.S.M., "A review on polycyclic aromatic hydrocarbons: Source, environmental impact, effect on human health and remediation", Egyptian Journal of Petroleum, 25, 107-123, 2016. Doi:10.1016/j.ejpe.2015.03.011.

[2] Rengarajan, T., Rajendran, P., Nandakumar, N., Lokeshkumar, B., Rajendran B., Nishigaki, I., "Exposure to polycyclic aromatic hydrocarbons with special focus on cancer", Asian Pacific Journal of Tropical Biomedicine, 5(3), 182-189, 2015. Doi: 10.1016/S2221-1691(15)30003-84.

[3] Cherrie, J., "Risks of Exposure to Hazardous Substances: Toxicology and Beyond, About Chemical Substances in the Workplace", European Agency for Safety and Health at Work presentation-EU-OSHA, 2009.

[4] Vincent, R., "CMR chemical substance inventory used in France in 2005 INRS - National Research and Safety Institute, Occupational Health, and Safety, Workbooks- 4th quartile", 2006.

[5] OSHwiki-EU-OSHA. Occupational safety and health (OSH) homepage on the Internet Web site, Access date: 18/11/2020, Available from:

https://oshwiki.eu/wiki/Category:Carcinogenic,_mutagenic,_reprotoxic_(CMR)_substances

[6] Li, K., Jing, Y., Yang, C., Liu, S., Zhao, Y., He, X., et al., "Increased leukemia-associated gene expression in benzene-exposed workers", Scientific Reports, 4, Article number: 5369, 2014. doi: 10.1038/srep05369.

[7] Kamal, A., Malik, R.N., "Hematological Evidence of Occupational Exposure to Chemicals and Other Factors among Auto-Repair Workers in Rawalpindi, Pakistan", Osong Public Health and Research Perspectives, 3(4), 29-238, 2012. Doi: 10.1016/j.phrp.2012.10.003.

[8] AFSSET - Ulusal Çevre Sağlığı ve Gıda Güvenliği Ajansı, Üreme Ve Gelişme Özellikli Toksik Madde Listesinin Belirlenmesi Ve Toksikolojik Referans Değerlerinin Analizi Için Bir Sıralama 
Yönteminin Önerilmesi ,'VTR reprotoksik' uzmanları, 58, 2006. Access date: 18/11/2020, Available from:

https://oshwiki.eu/wiki/Category:Carcinogenic,_mutagenic,_reprotoxic_(CMR)_substances

[9] Evans, T.J. "Endocrine disrupters", Gupta, R.C., (Ed.), Reproductive and Developmental Toxicity, Elsevier Inc. 874-875, 2011.

[10] Beardsley A, O' Donnell L. "Characterization of normal spermiation and spermiation failure induced by hormone suppression in adult rats", Biology of Reproduction, 68, 1299-1307, 2003. Doi: 10.1095/biolreprod.102.009811.

[11] Aladakatti, R.H., Nazeer A.R., "Changes in Sertoli cells induced by Azadirachta indica A. Juss leaves in albino rats", Journal of Basic and Clinical Physiology and Pharmacology, 16, 67-80, 2005. Doi: 10.1515/jbcpp.2005.16.1.67.

[12] Cho, S.I., Damokosh, A.I., Ryan, L.M., Chen, D., Hu, Y.A., Smith, T.J., Christiani, D.C., Xu $\mathrm{X}$., "Effects of exposure to organic solvents on menstrual cycle length", Journal of Occupational and Environmental Medicine, 43(6), 567-75, 2001. doi: 10.1097/00043764200106000-00012.

[13] Rogene, F.H., "Species Differences in the Metabolism of Benzene", Environmental Health Perspectives, 106 (6), 1173-1175, 1996. Doi: 10.1289/ehp.961041173.

[14] Ganousis, L.G., Goon, T., Zyglewska, K.K., Ross, W.D., "Metabolism in mouse Bone Marrow Stroma: Study of activation and detoxification of benzene metabolites", Molecular Pharmacology, 42 (6), 1118-1125, 1992. PMID: 1480134.

[15] Nemes, Z. JR., Friis, R.R., Aeschlimann, D., Saurer, S., Paulsson, M, Fesüs, L., "Expression and activation of tissue transglutaminase in apoptotic cells of involuting rodent mammary tissue”, European Journal of Cell Biology, 70 (2), 125-33, 1996. PMID: 8793384.

[16] Zeiss, C.J., "The Apoptosis- Necrosis Continuum: Insights from Genetically Altered Mice" Veterinary pathology, 40, 481-495, 2003. Doi: 10.1354/vp.40-5-481.

[17] White, E., "Death-defying acts: a meeting review on apoptosis" Genes and Development, 7, 2277- 2284, 1993. Doi: 10.1101/gad.7.12a.2277.

[18] Sharma, R., Bhat, R., Goyal, A., Bhardwaj, J.K., "Germ Cells Apoptosis during Spermatogenesis in Mammals", Journal of Entomology and Zoology Studies, 3(3), 506-515, 2015. ISSN 2320-7078.

[19] Mahdi, A., Rajender, S., Shukla, K., "Apoptosis, spermatogenesis and male infertility" Frontiers in Bioscience, 1(4), 746-754, 2012. Doi: 10.2741/415.

[20] National Research Council. Guide for the Care and Use of Laboratory Animals: Eighth Edition. Washington, DC: The National Academies Press. 2011. Doi: 10.17226/12910.

[21] Johnsen, S.G., "Testicular biopsy score count--a method for registration of spermatogenesis in human testes: normal values and results in 335 hypogonadal males" Hormones, 1(1), 2-25, 1970. Doi: 10.1159/000178170. 
[22] Joshi, D.R., Adhikari, N., "An Overview on Common Organic Solvents and Their Toxicity", Journal of Pharmaceutical Research International, 28(3), 1-18, 2019. Doi: 10.9734/jpri/2019/v28i330203.

[23] Cornish, H.H., Ryan, R.C. Metabolism of benzene in nonfasted, fasted, and aryl-hydroxylase inhibited rats. Toxicology and applied pharmacology, 7(6), 767-71, 1965. Doi: 10.1016/0041008x (65)90001-3.

[24] Withey, R.J., Hall, J.W. The joint toxic action of perchloroethylene with benzene or toluene in rats. Toxicology, 4 (1), 5-15, 1975. Doi: 10.1016/0300-483X (75)90017-7.

[25] Hsieh, G.C., Sharma, R.P., Parker, R.D.R. Subclinical effects of groundwater contaminants I: Alteration of and cellular immunity by benzene in CD-1 mice. Archives of Environmental Contamination and Toxicology, 17, 151-158, 1988. Doi: 10.1007/BF01056019.

[26] Singh, R.K., Bansode, F.W., "Benzene- induced histopathological changes and germ cell population dynamics in testes of Sprague Dawley rats", Journal of Environmental Biology, 32, 687- 694, 2011. ISSN: 02548704.

[27] Ravindranath, H., Aladakatti M.A., Nazeer A. R., Mukhtar A. G. Ghodesawar, "Effect of benzene leaf extract of Ocimum sanctum on testis and spermatogenic pattern in albino rats", International Journal of Current Research, 5, 22-29, 2010. ISSN: 0975-833X.

[28] Linder, R.E., Hess, R.A., Strader, L.F., "Testicular toxicity and infertility in male rats treated with 1,3- dinitrobenzene", Journal of toxicology and environmental health, 19(4), 477- 489, 1986. Doi: 10.1080/15287398609530946.

[29] Cárdenas-Valencia, I., Nieto, J., Gasco, M., Gonzales, C., Rubio, J., Portella, J., Gonzales, G.F., "Tropaeolum tuberosum (Mashua) reduces testicular function: effect of different treatment times. Andrologia, 40(6), 352-7, 2008. doi: 10.1111/j.1439-0272.2008.00868.x. PMID: 19032684.

[30] National Toxicology Program. "Toxicology and carcinogenesis studies of divinylbenzene- HP (Cas No. 1321- 74- 0) in F344/ N rats and B6C3F1 mice (inhalation studies)", National Toxicology Program technical report series, 18 (4), 9- 285, 2006. PMID: 17342197.

[31] Shi, Y., Song, Y., Wang, Y., Wang, Y., Liang, X., Hu, Y., Yu, H., Guan, X., Cheng, J., Yang, K. $\beta$-“Benzene hexachloride induces apoptosis of rat Sertoli cells through generation of reactive oxygen species and activation of JNKs and FasL", Environmental toxicology, 26(2), 124-135, 2011. Doi:10.1002/tox.20536. 